Tadao Okuno MD, Makoto Takeda MD, Masahide Horishi MD, Takeshi Okanoue MD, Tatsuro Takino MD

\title{
Hepatitis due to repeated inhalation of methoxyflurane in subanaesthetic concentrations
}

The authors present a case of hepatitis, which was due to repeated self-administered inhalation of methoxyfurane in subanaesthetic concentrations for insomnia. The diagnosis of viral hepatitis, type $A$ or type $B$, was excluded on the basis of serologic findings. This case is of particular interest in that methoxyfurane even in subanaesthetic concentrations caused hepatic damage on repeated exposure.

\section{Key words}

ANAESTHETICS: methoxyflurane, abuse; LIVER: hepatitis.

Methoxyflurane is a halogenated ether with a structure resembling that of halothane. Hepatitis following methoxyflurane anaesthesia has been reported..$^{1-4}$ However, reports usually relate to patients who have undergone methoxyflurane anaesthesia. Hepatitis due to methoxyflurane inhalation in low concentrations for obstetric analge$\mathrm{sia}^{5}$ or repeated sniffing of methoxyflurane as an euphoriant ${ }^{6}$ has been rarely reported.

We report a case of hepatitis which was due to repeated inhalation of methoxyflurane in subanaesthetic concentrations for insomnia.

\section{Case Report}

A 39-year-old male gynecologist was admitted to the Kyoto Prefectural University Hospital on

From The Third Department of Internal Medicine, Kyoto Prefectural University of Medicine, Kyoto, Japan Address correspondence to: Dr. Tadao Okuno, Third Department of Intemal Medicine, Kyoto Prefectural University of Medicine, Kawaramachi-Dori, HirokojiAgaru, Kamigyo-Ku, Kyoto, 602, Japan.
December 15, 1982, because of severe general malaise and jaundice. There was no history of previous hepatitis, blood transfusion, or general anaesthesia. He rarely drank alcohol. He had taken $5 \mathrm{mg}$ of diazepam orally for insomnia on occasion for the past several years. He had inhaled about $2 \mathrm{ml}$ of methoxyflurane once or twice almost every day for six weeks for insomnia, using an infiltrated gauze pad placed over his mouth. A $125 \mathrm{ml}$ bottle of methoxyflurane had been consumed in approximately one month. In late November, he developed loss of appetite and general malaise followed by dark urine. There was no fever. On December 10, he was jaundiced. At that time the serum total bilirubin was $12.3 \mathrm{ml} / \mathrm{dl}$, SGOT $528 \mathrm{KU}^{*}$, and SGPT $488 \mathrm{KU}$. Two days later, $10 \mathrm{mg}$ of prednisolone was given orally followed by $20 \mathrm{mg}$ on the next day. On December 14, $4 \mathrm{mg}$ of dexamethasone was given intravenously. On December 15 , he consulted a physician, because of increased general malaise and jaundice.

Physical examination on admission revealed a well developed, well nourished man. His sclera and skin were severely icteric. The liver and spleen were not palpable. There were no focal neurologic findings. The laboratory studies on admission revealed: WBC $10,400 / \mathrm{cu} \mathrm{mm,} \mathrm{RBC} 476 \times 10^{4} / \mathrm{cu}$ $\mathrm{mm}$, haemoglobin $15.0 \mathrm{~g} / \mathrm{dl}$, hematocrit 48 per cent and platelets $33 \times 10^{4} / \mathrm{cu} \mathrm{mm}$. There was no eosinophilia. Urinalysis revealed $2+$ reaction for urobilinogen, but was otherwise normal. The serum

*SGOT normal range, 12-31 Karmen Units. SGPT normal range, 3-33 Karmen Units. Alkaline phosphatase normal range, 4-10 King-Armstrong Units. Total protein normal range, $6.5-8.0 \mathrm{~g} / \mathrm{dl}$. Albumin normal range, $3.7-5.2 \mathrm{~g} / \mathrm{d} 1$. $\gamma$-globulin normal range, $0.6-1.7 \mathrm{~g} / \mathrm{d}$. 


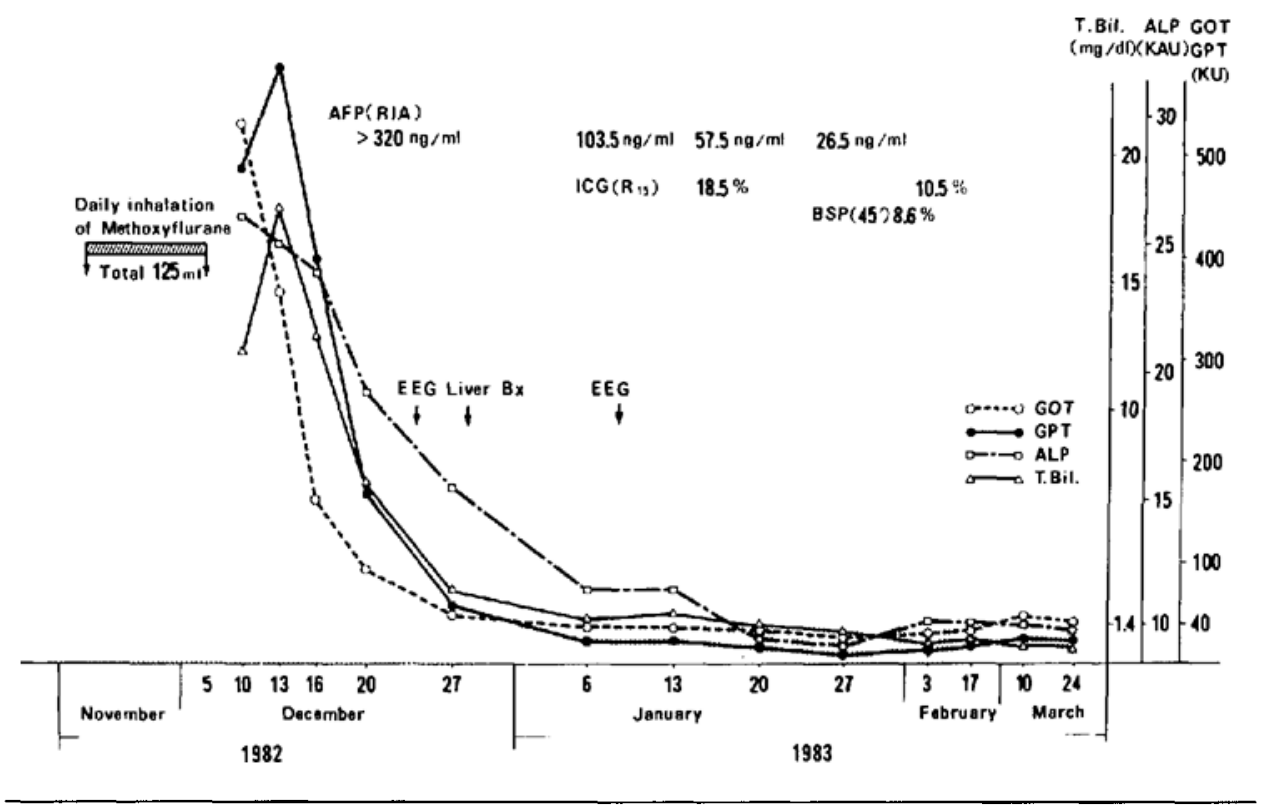

FIGURE Sequential results of liver function test. The stippled arca represents the normal ranges of total bilirubin (T. Bil.), SGOT, SGPT and ALP (alkaline phosphatase). AFP $=\alpha$-fctoprotein, $\mathrm{RIA}=$ radioimmunossay; $\operatorname{ICG}\left(\mathrm{R}_{15}\right)=$ indocyamine green (15 min.); BSP $\left(45^{\prime}\right)=$ bromsulphatein test ( 45 min.).

total bilirubin was $12.7 \mathrm{mg} / \mathrm{dl}$, SGOT $165 \mathrm{KU}$, SGPT $400 \mathrm{KU}$, alkaline phosphatase $23.8 \mathrm{KAU}$, $\gamma$-GTP $196 \mathrm{mU} / \mathrm{ml}$, and LAP 367 GRU (normal range, 86-240). He had a total protein of $6.6 \mathrm{~g} / \mathrm{dl}$ with an albumin of $3.9 \mathrm{~g} / \mathrm{dl}$ and a $\gamma$-globulin of 1.5 $\mathrm{g} / \mathrm{dl}$. The serum ammonia was $91.8 \mu \mathrm{g} / \mathrm{dl}$ (normal range, 19-79). An abdominal ultrasonographic study did not reveal any evidence of biliary tract obstruction. HBsAg in serum was negative and anti-HBs positive, both determined by radioimmunoassay. Anti-HBc was $2^{4}$, determined by the immune adherence haemoagglutination (IAHA) method. IgM-anti-HAV was also negative. Therefore, the diagnosis of viral hepatitis, type $A$ as well as type $B$ was excluded. During the first four hospital days, the patient's condition was unchanged. A psychiatric consultation was obtained and a diagnosis of symptomatic psychosis was made, probably related to his hepatitis. The initial EEG tracing showed normal alpha wave and 8-9 cycle per second slow alpha wave with voltages between 50 and 80 microvolts. There were some 5-7 cycle per second theta waves, but no delta waves noted.
Needle biopsy of the liver performed on December 27 showed a confluent liver cell necrosis, predominantly centrilobular to midzonal, with a few inflammatory cell infiltration. There was no Kupffer cell mobilization. The changes of the portal tracts were minimal. The electron microscopic study of the liver tissue revealed that there were many irregularly shaped vacuoles, partially enveloped by a membrane, resembling fat droplets and an increased number of secondary lysosomes in hepatocytes. The intercellular spaces were dilated with well-developed microvilli. The course of the illness was subsequently uneventful with complete resolution of the clinical and biochemical abnormalities (Figure). He was discharged from hospital on the 52nd hospital day.

\section{Discussion}

Methoxyflurane anaesthesia has been frequently associated with nephrotoxicity, and on occasion with hepatic injury, similar to halothane hepatitis. The published case reports, however, are relatively few in number. In 1974, Joshi and Conn ${ }^{7}$ reviewed 24 reported cases of methoxyflurane hepatitis. Half 
the patients had previously been exposed to halothane or methoxyflurane. Fever was the presenting symptom in half the patients and appeared from a few hours to 14 days after surgery. Clinical evidence of hepatitis appeared shortly thereafter.

Cases of methoxyflurane hepatitis were usually reported in patients who had undergone anaesthesia. Rubinger et al. ${ }^{5}$ reported a case of hepatitis following the exposure to methoxyflurane in subanaesthetic concentrations for obstetric analgesia. Min et $a l .^{6}$ also reported a case of fulminant hepatitis due to repeated sniffing of methoxyflurane as an euphoriant.

In the present case, the patient had been repeatedly inhaled methoxyflurane in subanaesthetic concentrations during one-month period before the development of icteric hepatitis. The diagnosis of viral hepatitis, type $A$ as well as type B was excluded on the basis of serological findings. The clinico-pathological features of this patient's disease were consistent with methoxyflurane associated hepatitis. Methoxyflurane continues to be in use in Japan, although the clinical utility of this agent is severely limited by its nephrotoxicity.

Modern volatile anaesthetics have been abused, most commonly by hospital personnel. ${ }^{8-11}$. Several deaths due to halothane, ${ }^{8-11}$ enflurane $e^{10-13}$ and methoxyflurane ${ }^{6}$ abuse have been reported. Bressler $^{14}$ reported that 20-30 per cent of the suicides in the medical community were related to drug abuse and 40 per cent to alcohol. Therefore, every effort must be made to prevent the illicit use of volatile anaesthetics. This case is of particular interest in that methoxyflurane even in subanaesthetic concentrations causes hepatic damage on repeated exposure.

\section{Acknowledgments}

The authors thank Dr. Yoshiko Okuno, Anaesthesiologist in Chief, The First Red Cross Hospital of Kyoto for her criticism and suggestions and Miss Chisako Nakagawa for typing the manuscript.

\section{References}

1 Klein NC, Jeffries, G.H. Hepatotoxicity after methoxyflurane administration. JAMA 1966; 197: 1037-9

2 Lischner, MW, MacNabb GM, Galambos JT. Fatal hepatic necrosis following surgery. Possible relation to methoxyflurane anesthesia. Arch Intern Med 1967; 120: 724-8.
3 Stefanini $M$, Herland A, Kosyak, EP. Fatal massive necrosis of the liver after repeated exposure to methoxyflurane. Anesthesiology 1970; 32: 374-8.

4 Brenner AI, Kaplan MM. Recurrent hepatitis due to methoxyflurane anesthesia. N Engl J Med 1971; 284: 961-2.

5 Rubinger D, Davidson JT, Melmed RN. Hepatitis following the use of methoxyflurane in obstetric analgesia. Anesthesiology 1975; 43: 593-5.

6 Min K-W, Cain GD, Sabel JS, Gyorkey $F$. Methoxyflurane hepatitis. Southern Med J 1977; 70: 1362-4.

7 Joshi PH, Conn HO. The syndrome of methoxyflurane associated hepatitis. Ann Intern Med 1974; 80: 395-401

8 Spencer $J A$, Green $N M$. Suicide by ingestion of halothane. JAMA 1968; 205: 702-3.

9 Spencer JD, Raasch FO, Trefny FA. Halothane abuse in hospital personnel. JAMA 1976; 235: 1034-5.

10 Yamashita $M$, Matsuki A, Oyama $T$. Illicit use of modem volatile anaesthetics. Can Anaesth Soc J 1984; 31: 76-9.

11 Block $S$, Rosenblatt $R$. A halothane-abuse fatality. Anesthesiology 1980; 52: 524

12 Kaplan HG, Bakken J, Quadracci L, Schubach W. Hepatitis caused by halothane sniffing. Ann Intern Med 1979; 90: 797-8.

13 Lingenfelter $R W$. Fatal misuse of enflurane. Anesthesiology 1981; 55: 603.

14 Bressler $B$. Suicide and drug abuse in the medical community. Suicide Life Threat Behav 1976; 6: 169-78.

Résumé

Les auteurs rapportent un cas d' hépatite due d̀ l'administration répétée de méthoxyflurane en concentrations subanesthésiques contre l'insomnie. Le diagnostic d'hépatite virale type $A$ ou type $B$ a été éliminé par l'investigation sérologique. Ce cas apparaît d' un grand intérêt car il montre que le méthoxyflurane, en doses subanesthésiques administrées de façon répétée, peut causer des dommages hépatiques. 